\title{
Synergistic action of rutin and orthovanadate on nitric oxide release from mouse macrophage cells
}

\author{
S. Koncz*, Edit J. Horváth \\ *IZINTA Trading Co., Budapest, Hungary \\ Institute for Drug Research, Budapest, Hungary
}

Received:August 31, 1999

Accepted: January 13, 2000

\begin{abstract}
The cooperative action of sodium orthovanadate (a putative protein-phosphotyrosine phosphatase inhibitor) and rutin (an effective superoxide scavenger) on the nitric oxide (NO) production of J774A.1 mouse macrophage cells has been investigated. Orthovanadate alone caused a mild but significant increase in NO production of the cells at its highest concentration used $(500 \mu \mathrm{M})$. Orthovanadate and rutin together caused a significant increase in the nitrite level of the supernatants of the J774A.1 cells after a 24-hour incubation period, in a concentration dependent manner. The optimal doses for orthovanadate and rutin were $50 \mu \mathrm{M}$ and $100 \mu \mathrm{M}$, respectively. This cooperative action of rutin and orthovanadate was totally inhibitable by catalase, reduced glutathion, $\mathrm{N}$-acetylcystein, cycloheximide, pyrrolidine dithiocarbamate (a putative NF-KB inhibitor), genistein and tyrphostin-AG126 (two protein tyrosine-kinase inhibitors). Superoxide dismutase had no inhibitory effect. Orthovanadate and rutin (only together) could induce the oxidation of $2^{\prime}, 7^{\prime}$-dichlorofluorescein-diacetate, a marker of hydrogen peroxide. This effect was inhibitable by reduced glutathion, a hydrogen peroxide specific scavenger. These findings suggest, that orthovanadate can induce the production of NO by J774A.1 macrophages not only by inhibition of protein tyrosine-phosphatases, but, using it with rutin, by increasing the level of hydrogen peroxide in the cells.
\end{abstract}

line

Keywords: sodium orthovanadate, rutin, hydrogen peroxide, nitric oxide, J774A.1 cell

Orthovanadate $\left(\mathrm{VO}_{4}{ }^{3-}\right)$ is known as a protein tyrosine phosphatase inhibitor [1], that can also potentiate phorbol-12-myristate-13-acetate (PMA) induced superoxide generation in rat alveolar macrophages upon prolonged incubation [2], stimulates the

Correspondence should be addressed to Sándor Koncz

IZINTA Trading Co., Budapest, Hungary

Fax: (36)-(1)-395-9049 
MAP kinase pathway and phosphatidylinositol 3-kinase [3]. Orthovanadate has been previously reported to induce expression of several genes in mouse C127 cells: actin, cHa-ras and c-jun [4]. The action of orthovanadate on these genes was altered by hydrogen peroxide $\left(\mathrm{H}_{2} \mathrm{O}_{2}\right)$ and was not affected either by the tyrosine kinase inhibitor genistein or the PKC activator PMA. Orthovanadate can also potentiate IL-1 betainduced nitric oxide (NO) release to the medium from the insulin producing cell line RINm-5F via inhibition of protein tyrosine phosphatases [5], and cause synthesis of endothelium-derived $\mathrm{NO}$ in pigs via endothelial tyrosine kinases and pertussis toxinsensitive G-proteins [6]. NO plays a key role in the defense mechanisms of the immune system and in the pathogenesis of some inflammatory and non-inflammatory diseases. In macrophages, the inducible, $\mathrm{Ca}^{2+} /$ calmodulin independent nitric oxide synthase enzyme (iNOS) is responsible for the production of high amounts of NO contributing to the cytotoxic properties of these cells against target cells [7]. Among flavonoids, there are several compounds with effective NO scavenging activity [8]. Quercetin and its 3rutinoside derivative, rutin are known cytoprotective agents against oxidative injury [9-12]. Also, rutin enhances the production of tumor necrosis factor-alpha of murine macrophages [13], inhibits phospholipase A2 [14] and topoisomerase IV [15]. The influence of rutin on the iNOS-inducing action of sodium orthovanadate on J774A.1 mouse macrophages has been investigated.

\section{Materials and methods}

\section{Materials}

2',7'-dichlorofluorescein-diacetate (DCFH-DAC) was purchased from Molecular Probes Inc. (Eugene, Oregon, USA). Lymulus Amebocyte Lysate Test (LAL Test) was purchased from Whittaker Bioproducts (Walkersville, MD, USA). Diosmin was purchased from Aldrich Chemie GmbH (Steinheim, Germany). Catalase (E.C. 1.11.1.6.) and hydrogen peroxide $(30 \%)$ were purchased from Reanal Finechemical Co. (Budapest, Hungary). All other reagents and test compounds were purchased from Sigma Chemical Co. (St. Louis, MO, USA).

\section{Effects on NO synthesis and viability of J774A.1 cells}

J774A.1 mouse macrophage cells (ATCC TIB-67, Rockville, MD, USA) were maintained in RPMI-1640 (90\%), FBS (10\%) medium [16]. The potential LPS contamination of the medium during the propagation of cells was checked by the LAL Test. For experiments, J774A.1 cells were thoroughly washed with FBS-free 
RPMI-1640 medium and seeded out at the concentration of $10^{5}$ cells/well in 96-well plates in RPMI-1640 medium (without phenol-red, named as medium in the text below).

Test compounds rutin, quercetin, genistein, cycloheximide, tyrphostin-AG126 and pyrrolidine-dithiocarbamate (PDTC) were dissolved $(0.1 \mathrm{M})$ in dimethyl sulfoxide (DMSO), and were further diluted by medium. Sodium orthovanadate, reduced glutathione (GSH), oxidized glutathione (GSSG) and N-acetylcysteine (NAC) were dissolved directly in medium. LPS (E. coli, 055:B5) was diluted directly in FBS from a stock solution of $200 \mu \mathrm{g} / \mathrm{ml}$, and it was used at the optimal concentration of $100 \mathrm{ng} / \mathrm{ml}$ on the cells.

The total volume of medium was $100 \mu 1 /$ well. After a 24-hour incubation period, the nitrite content of the supernatants (triplicates in all experiments) was measured by the Griess reaction adapted for a 96-well plate reader [17]. Briefly, $50 \mu 1$ of Griess reagent $(1 \% \mathrm{w} / \mathrm{v}$ sulphanilamide and $0.1 \% \mathrm{w} / \mathrm{v}$ naphthylethylenediamine in $5 \% \mathrm{v} / \mathrm{v}$ phosphoric acid) was added to $50 \mu \mathrm{l}$ of sample culture medium, and the plates were read after a 10 minutes incubation time, at room temperature (Elx800 ELISA Reader, Bio-Tek Instruments, Inc., Winooski, VT, USA). In all experiments, $\mathrm{N}^{\mathrm{G}}$-nitro-Larginine (L-NOARG) was used as control at the final concentration of $1 \mathrm{mM} \mathrm{[18].}$

ANOVA and Newman-Keuls test was used to determine the significance between the means. The differences have been taken as significant in case of $\mathrm{P}<0.05$.

After the experiments, the viability of J774A.1 cells were checked by 3-(4,5Dimethylthiazol-2-yl)-2,5-diphenyl-tetrazolium bromide (MTT) using the method of Schmitt et al. [11], and measured at 550/690 nm by Elx800 ELISA Reader. The viability of untreated cells has been taken as $100 \%$.

\section{Effects on DCFH-DAC oxidation and optical spectra}

The effect of rutin and sodium orthovanadate on the oxidation of DCFH-DAC was measured by the method of Roy et al. [19] with a little modification. Briefly, the J774A. 1 cells $\left(10^{6} / \mathrm{ml}\right.$ in $1.5 \mathrm{ml}, 0.01 \mathrm{M}$ PBS, $\left.\mathrm{pH}=7.4\right)$ have been incubated at $37^{\circ} \mathrm{C}$ with DCFH-DAC (at the final concentration of $10 \mu \mathrm{M}$ ) for 2 minutes. The changes in fluorescence were measured at $\mathrm{E}_{\mathrm{x}}=503 \mathrm{~nm}$ and $\mathrm{E}_{\mathrm{m}}=520 \mathrm{~nm}$ after adding the test compounds, using a computer-controlled SHIMADZU-RF2001 spectrofluorimeter. The effects of GSH on DCFH-DAC oxidation were also measured by the same method.

Optical spectra were recorded by Specord Spectrophotometer (Carl Zeiss GmbH, Jena, Germany) [25] 


\section{Results}

Effects of orthovanadate and rutin on NO synthesis

At the concentrations used none of the compounds affected the Griess reaction.

The lack of FBS in the medium of J774A. 1 cells caused no nitric oxide synthesis of LPS $(100 \mathrm{ng} / \mathrm{ml})$ treated cells (data not shown). Therefore, the potential LPS contamination of the compounds could not cause NO synthesis of the cells. Sodium orthovanadate $\left(\mathrm{Na}_{3} \mathrm{VO}_{4}\right)$ has been tested alone or in combination with rutin at different concentrations. Orthovanadate alone was able to induce some NO synthesis only at the concentration of $500 \mu \mathrm{M}(5 \mu \mathrm{M}$ nitrite in the supernatants, data not shown). Rutin alone was unable to induce NO synthesis (data not shown). In combination, the most effective doses were $50 \mu \mathrm{M}$ for orthovanadate and $100 \mu \mathrm{M}$ for rutin (Fig. 1). The absolute values of the measured nitrite concentrations in the supernatants of the cells varied between 7 and $40 \mu \mathrm{M}$, and were always significantly higher than that of the control values $(0-1.5 \mu \mathrm{M})$. The effect of the preincubation time has been also investigated. The highest nitrite content was measured when rutin and orthovanadate were added at the same time to the cells (data not shown). In the following experiments, rutin and orthovanadate were added to the cells at the same time at the concentrations of $100 \mu \mathrm{M}$ and $50 \mu \mathrm{M}$, respectively. The amount of the released NO in the medium increased with the increasing incubation period. The plateau has been reached at 48 hour (data not shown). L-NOARG, used at the concentration of $1 \mathrm{mM}$, always lowered the nitrite content of the supernatants of the cells by about $90-100 \%$, without affecting the viability of cells negatively (data not shown). To reveal which part of the structure of rutin is responsible to this cooperative effect with orthovanadate, quercetin and diosmin were also tested in our system. According to our results, quercetin had a similar effect (Fig. 2), but its effective concentration was lower than that of rutin $(10 \mu \mathrm{M}$ and $100 \mu \mathrm{M}$, respectively). Because of its low solubility, diosmin was added in the concentration range of $0.08-10 \mu \mathrm{M}$ to the cells with $50 \mu \mathrm{M}$ orthovanadate. At these concentrations, diosmin did not cause significant increase in NO synthesis of J774A.1 cells. At higher concentrations $(50-250 \mu \mathrm{M})$, diosmin precipitated during the incubation period (24 hours), but did not induce NO synthesis either with or without orthovanadate (data not shown).

Effects of specific inhibitors and scavengers

The effects of GSH, GSSG, NAC, cycloheximide, PDTC, tyrphostin-AG126, genistein, catalase and superoxide dismutase (SOD; E.C. 1.15.1.1.) were investigated giving them together with rutin $(100 \mu \mathrm{M})$ and orthovanadate $(50 \mu \mathrm{M})$ to the cells. 


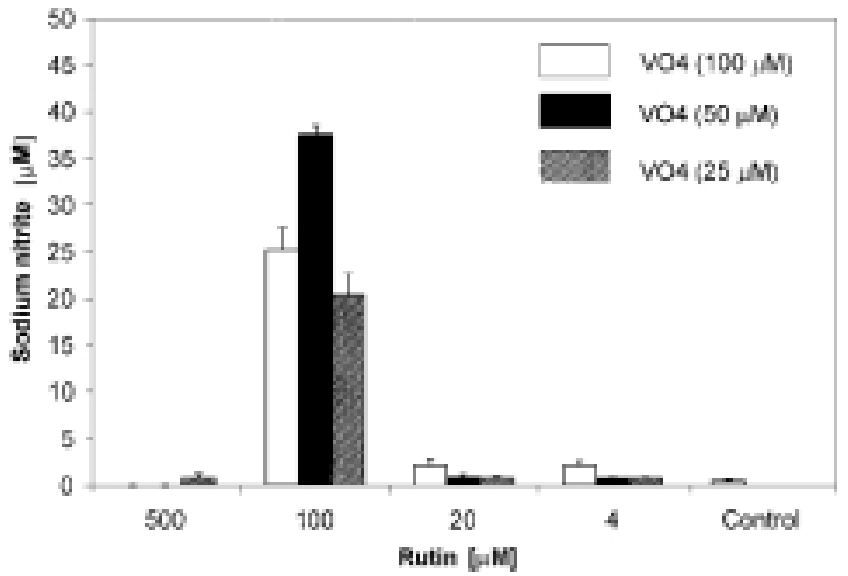

Fig. 1. Effect of sodium orthovanadate in combination with rutin on the nitric oxide production of J774A.1 cells. The mean values of triplicates \pm standard deviations (S.D.) are represented of a representative of at least five experiments with similar results. The differences between the nitrite content of the supernatants were significant $(\mathrm{P}<0.05)$ in cases of $100 \mu \mathrm{M}$ rutin, as compared to the control value

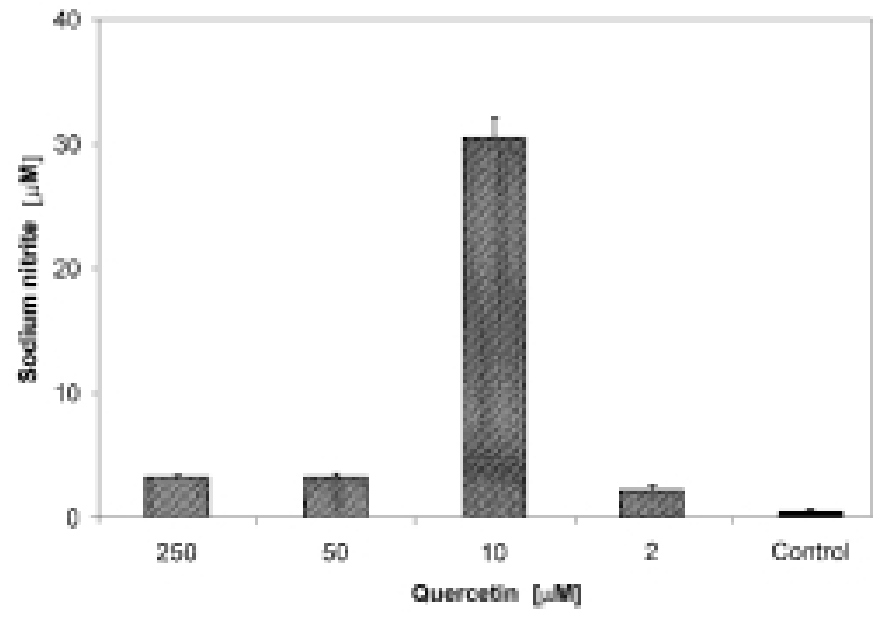

Fig. 2. Effect of quercetin plus orthovanadate $(50 \mu \mathrm{M})$ on the NO synthesis of J774A.1 cells. The means \pm S.D. values of triplicates of a representative of two experiments with similar results are shown. The differences between the nitrite content of the supernatants were significant $(\mathrm{P}<0.05)$ in case of $10 \mu \mathrm{M}$ quercetin plus $50 \mu \mathrm{M}$ orthovanadate, as compared to the control value 
The hydrogen peroxide scavengers GSH, NAC [20-22], and catalase could inhibit the effect of rutin+orthovanadate without affecting the cell viability negatively (Fig. 3A, B). Cycloheximide, PDTC, genistein and tyrphostin-AG126 [23, 24] also inhibited the NO synthesis dose dependently, induced by rutin and orthovanadate (data not shown).
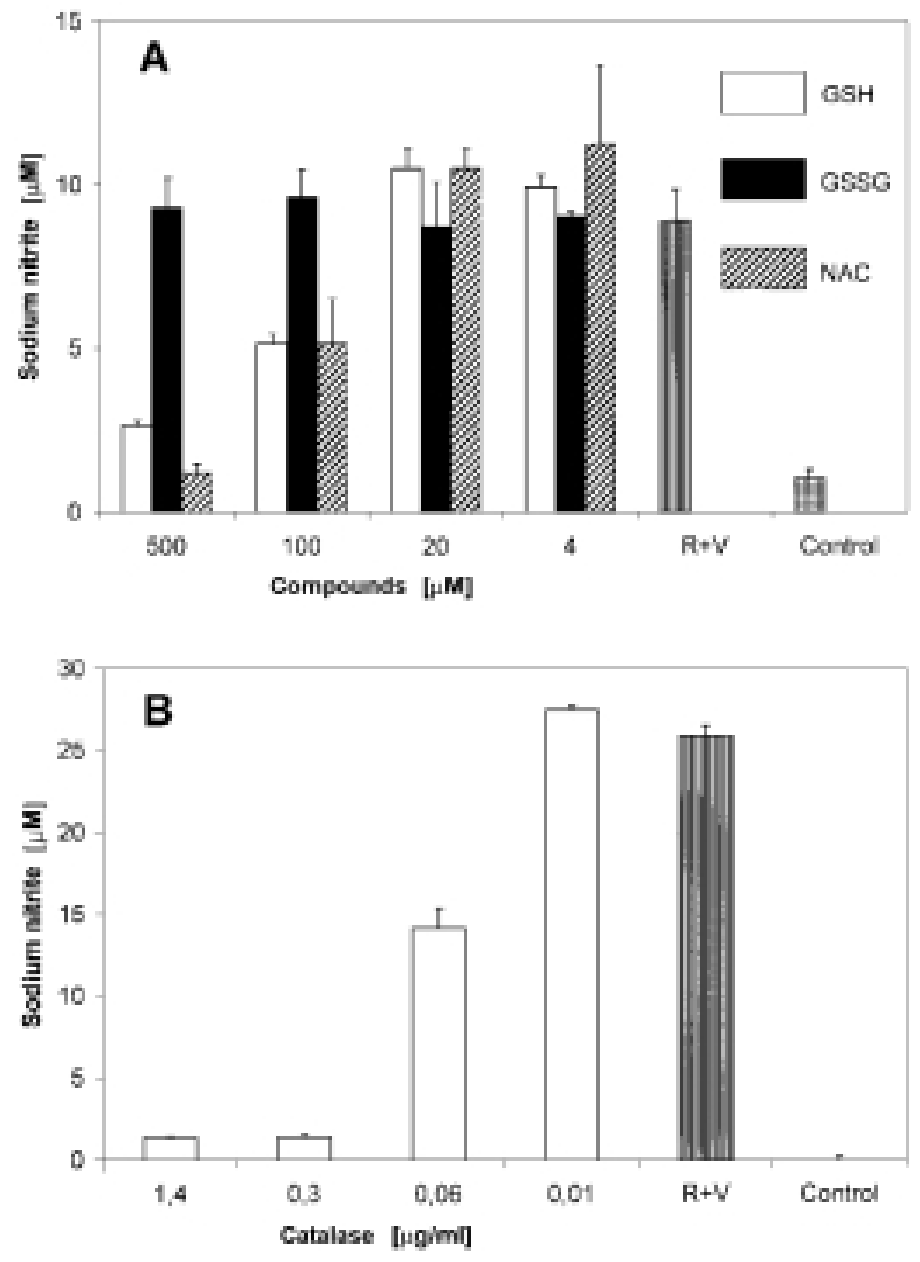

Fig. 3. Effects of GSH, GSSG, NAC (panel A) and catalase (panel B) on the rutin (R, $100 \mu \mathrm{M})$ plus orthovanadate $(\mathrm{V}, 50 \mu \mathrm{M})$ induced NO synthesis of J774A.1 cells. Means of triplicates \pm S.D. values of a representative experiment are shown. Similar results have been obtained in at least three experiments. The differences between the nitrite contents were significant $(\mathrm{P}<0.05)$ in all cases of rutin+orthovanadate, as compared to the control values. The differences between the nitrite contents were significant at the highest concentrations of the drugs (except for GSSG), as compared to the values of rutin+orthovanadate 
Only PDTC caused a significant decrease in the cell viability at the concentration of $500 \mu \mathrm{M}$, that could be inhibitory to the NO synthesis by itself ( $4 \%$ of viability, as compared to the control). SOD had no effect on the action of rutin+orthovanadate at the concentrations used (4-500 U/ml; data not shown).

\section{Effects of hydrogen peroxide}

In the further experiments, hydrogen peroxide $\left(\mathrm{H}_{2} \mathrm{O}_{2}\right)$ was used alone, or in combination with rutin, orthovanadate and rutin+orthovanadate, at different concentrations. Hydrogen peroxide alone did not cause NO synthesis of J774A.1 cells, but the cell viability decreased with its increasing concentration (4\% of viability at the highest concentration of $\left.5 \mathrm{mM} \mathrm{H}_{2} \mathrm{O}_{2}\right)$. In combination with orthovanadate $(50 \mu \mathrm{M})$, hydrogen peroxide was able to induce $\mathrm{NO}$ synthesis at the optimal concentration of $20 \mu \mathrm{M} \mathrm{H} \mathrm{H}_{2} \mathrm{O}_{2}$ (Fig. 4). At higher concentrations ( 100 and $500 \mu \mathrm{M}$ of $\mathrm{H}_{2} \mathrm{O}_{2}$ ), the cell viability dramatically decreased. In case of rutin $(100 \mu \mathrm{M})+$ orthovanadate $(50 \mu \mathrm{M})$, hydrogen peroxide lowered the production of NO with decreasing cell viability (under $20 \%$ of viability, as compared to the control cells). These effects of hydrogen peroxide with orthovanadate could be inhibited by catalase, PDTC, cycloheximide, tyrphostin-AG126 and genistein in a dose dependent manner, similarly to rutin+orthovanadate (data not shown).

\section{Effects on the LPS induced NO synthesis}

Rutin+orthovanadate increased the NO production induced by LPS. The same effect was seen in case of orthovanadate plus LPS. In contrast, rutin alone decreased the NO production induced by LPS (Fig. 5).

\section{Effects on the cell viability}

The investigation on the toxicity of rutin+orthovanadate toward the J774A.1 cells (MTT-test) have revealed, that the cell viability did not affect the NO producing capability of the cells above $\sim 20 \%$ of viability (giving the viability of untreated control cells as $100 \%$; data not shown).

\section{Effects on DCFH-DAC oxidation}

The studies on the effects on DCFH-DAC oxidation have revealed, that DCFH-DAC was not oxidized by rutin and orthovanadate in a cell free system (data not shown). 


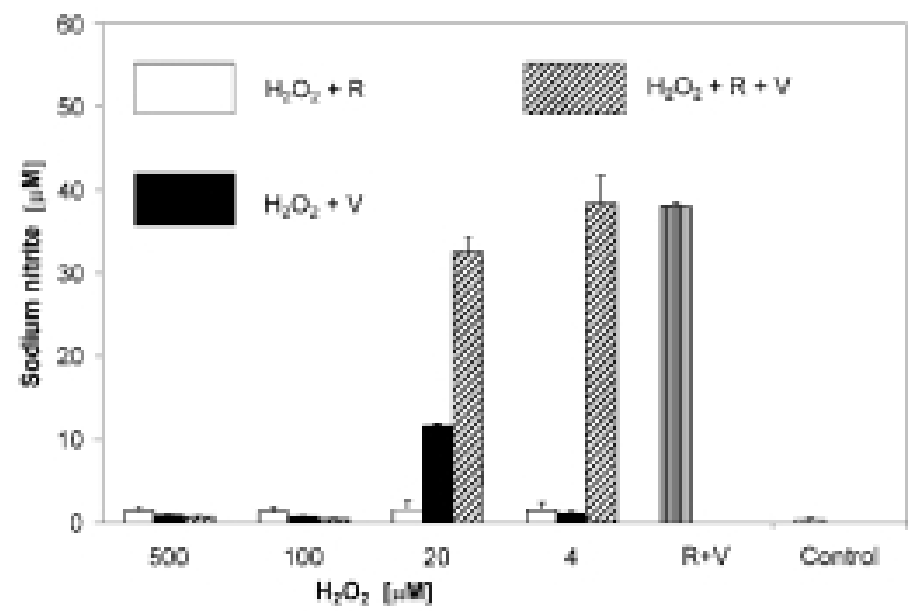

Fig. 4. Effect of hydrogen peroxide $\left(\mathrm{H}_{2} \mathrm{O}_{2}\right)$ on the NO production of J774A.1 cells. $\mathrm{H}_{2} \mathrm{O}_{2}$ was used in combination with rutin $(\mathrm{R}, 100 \mu \mathrm{M})$, orthovanadate $(\mathrm{V}, 50 \mu \mathrm{M})$ or rutin+orthovanadate $(\mathrm{R}+\mathrm{V}, 100 \mu \mathrm{M}$ and $50 \mu \mathrm{M}$, respectively). Means of triplicates \pm S.D. values of a representative experiment are shown. Similar results have been obtained in at least three experiments. The differences between the nitrite content of the supernatants were significant $(\mathrm{P}<0.05)$ in case of $20 \mu \mathrm{M} \mathrm{H}_{2} \mathrm{O}_{2}$ plus $50 \mu \mathrm{M}$ orthovanadate, as compared to the control value. The inhibitory effects of $\mathrm{H}_{2} \mathrm{O}_{2}$ on NO synthesis induced by rutin+orthovanadate were significant in cases of $500 \mu \mathrm{M} \mathrm{H}_{2} \mathrm{O}_{2}$ and $100 \mu \mathrm{M} \mathrm{H}_{2} \mathrm{O}_{2}$, as compared to the value of rutin+orthovanadate. The differences between the nitrite contents were significant $(\mathrm{P}<0.05)$ in case of rutin+orthovanadate, as compared to the control value

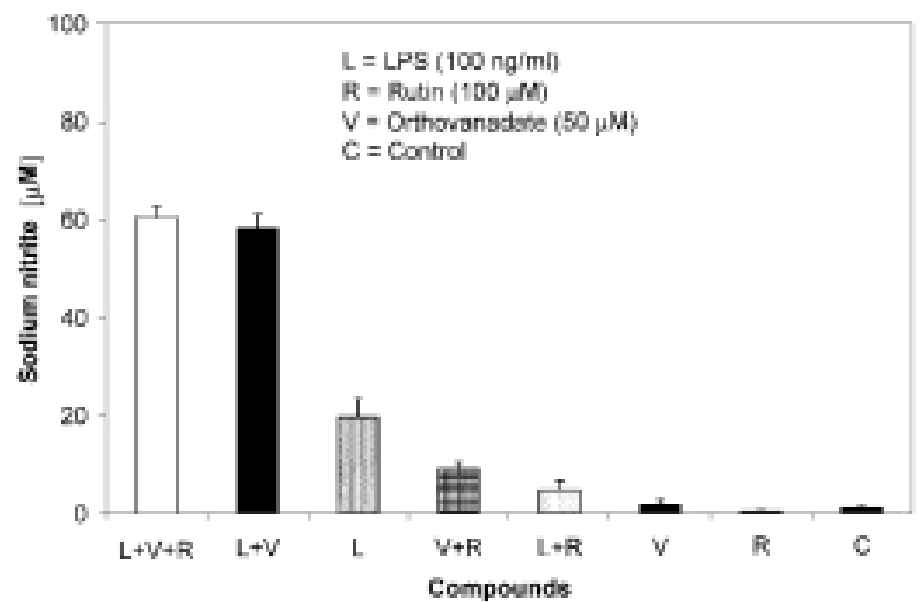

Fig. 5. Effect of rutin and orthovanadate on the NO synthesis of J774A.1 cells. Means of triplicates \pm S.D. values of a representative experiment are shown. Similar effects have been obtained in at least three experiments. The differences between the nitrite contents of the supernatants were significant $(\mathrm{P}<0.05)$ in case of $\mathrm{L}+\mathrm{R}+\mathrm{V}, \mathrm{L}+\mathrm{V}, \mathrm{L}, \mathrm{V}+\mathrm{R}$ and $\mathrm{L}+\mathrm{R}$, as compared to the control value. The difference between the nitrite content of $\mathrm{L}$ and $\mathrm{L}+\mathrm{R}$ was also significant 
The same effect was seen with J774A.1 cells using rutin or orthovanadate alone, but the mixture of these two compounds caused a significant increase in the amount of oxidized DCF (Fig. 6A). Surprisingly, the overdose of orthovanadate $(1 \mathrm{mM})$ over rutin $(0.1 \mathrm{mM})$ did not cause DCFH-DAC oxidation (Fig. 6A).
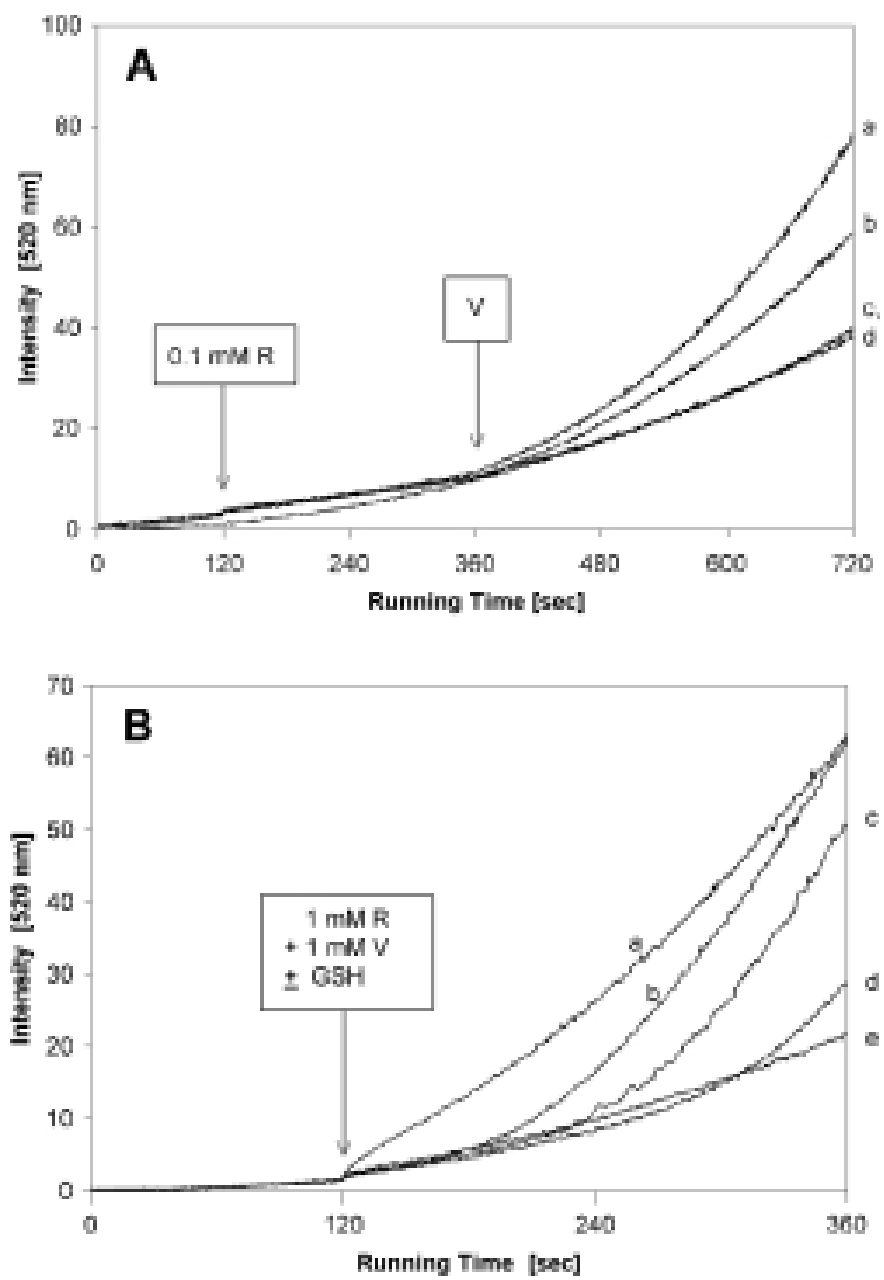

Fig. 6. Effects of rutin (R), orthovanadate (V) and reduced glutathione (GSH) on the oxidation of DCFH-DAC. J774A.1 cells $\left(10^{6} \mathrm{cells} / \mathrm{ml}\right)$ have been incubated with $10 \mu \mathrm{M}$ DCFH-DAC in $0.01 \mathrm{M}$ PBS for 2 minutes before adding the drugs at the concentrations signed. The oxidation was followed at $\mathrm{E}_{\mathrm{x}}=503 \mathrm{~nm}$ and $\mathrm{E}_{\mathrm{m}}=520 \mathrm{~nm}$. The concentrations of $\mathrm{V}$ in panel A were $0.5 \mathrm{mM}$ (a), $0.01 \mathrm{mM}$ (b), $1 \mathrm{mM}$ (c) and $0 \mathrm{mM}$ (d; control). The concentrations of GSH in panel B were $0 \mathrm{mM}$ (a; control), $0.1 \mathrm{mM}$ (b), $0.2 \mathrm{mM}$ (c), $0.3 \mathrm{mM}(\mathrm{d})$, and $1 \mathrm{mM}(\mathrm{e})$. Data from single experiments are shown. Similar results were obtained in at least two independent experiments 
This effect shows that orthovanadate can react with hydrogen peroxide produced by its reaction with rutin. In the reaction mixture, the concentration of DMSO was $1 \%$, and it did not affect the oxidation of DCFH-DAC (data not shown). GSH could inhibit the action of rutin+orthovanadate, in a dose dependent manner (Fig. 6B).

\section{Absorption spectra}

The absorption spectrum of rutin+orthovanadate against rutin (both in PBS) revealed that these two compounds form a complex in their solution (Fig. 7), similarly to the ferrous-ion-rutin complex [25]. There are new maximum sites in the spectrum of rutin: $278 \mathrm{~nm}, 310 \mathrm{~nm}$ and $408 \mathrm{~nm}$.

\section{Discussion}

The action of orthovanadate and rutin on nitric oxide synthesis of J774A.1 mouse macrophage cells has been investigated. Among the compounds tested only rutin (quercetin-3-rutinoside) and its aglycone counterpart, quercetin were able to induce NO synthesis in synergy with orthovanadate. Neither rutin nor orthovanadate caused significant NO production of the cells, using them alone. The inhibitory action of cycloheximide, a protein synthesis inhibitor [26] and that of L-NOARG [18] means that the inducible form of nitric oxide synthase (iNOS) has been activated.

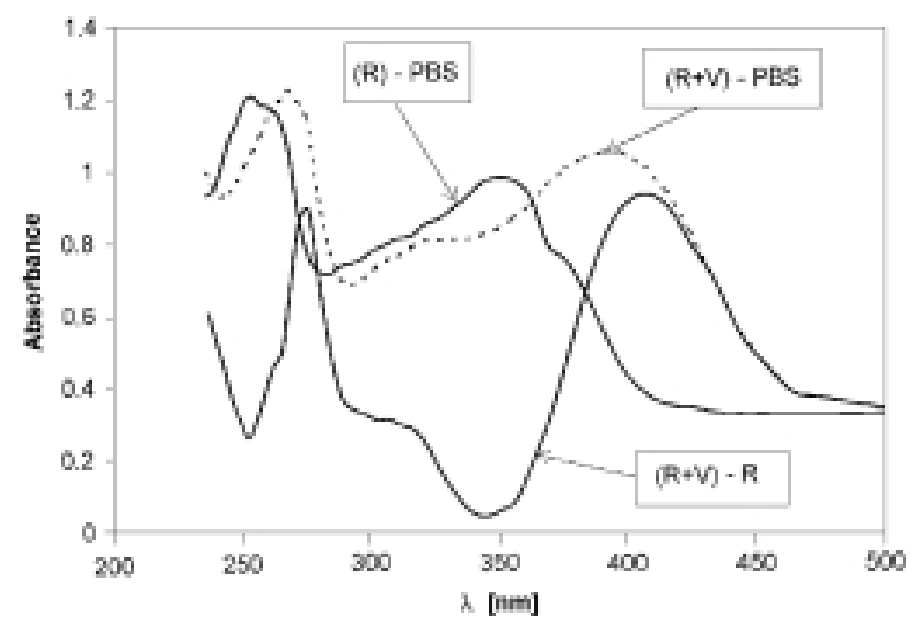

Fig. 7. Absorption spectra of rutin $(50 \mu \mathrm{M})$ alone against $0.01 \mathrm{M}$ PBS (R-PBS) and rutin plus orthovanadate (50 $\mu \mathrm{M}$ and $100 \mu \mathrm{M}$, respectively) against $0.01 \mathrm{M}$ PBS [(R+V)-PBS] or against $50 \mu \mathrm{M}$ rutin [(R+V)-R], as recorded by SPECORD spectrophotometer 
Diosmin, another rutinose containing antioxidant flavonoid (3',5,7-tetrahydroxy-4'methoxyflavone-7-rutinoside) [27], neither caused NO synthesis alone nor in combination with orthovanadate. These data suggest that the rutinose side chain did not play a key role in the action of rutin.

As rutin has a strong superoxide scavenging activity at neutral $\mathrm{pH}[28,29]$, and because of the fact, that DCFH-DAC is not sensitive to the superoxide anion [30, 31], the role of superoxide anion in the action of rutin+orthovanadate could be complately excluded. This is also supported by the facts, that GSH and NAC [20,21] could inhibit the action of rutin+orthovanadate on J774A.1 cells, and GSH inhibited DCFH-DAC oxidation. However, vanadate can potentiate PMA induced superoxide generation [2], SOD [32] was unable to inhibit the action of rutin+orthovanadate on J774A.1 cells. In contrast, catalase, a hydrogen peroxide scavenging enzyme [33], could inhibit the production of NO, parallel with increasing cell viability. These results suggest that the first step of induction of $\mathrm{NO}$ synthesis by rutin+orthovanadate is the production of hydrogen peroxide outside the cells.

The possibility of reaction between these two molecules (rutin+orthovanadate) is supported by their complex formation ability, and by their joint action on DCFH-DAC oxidation. The fact, that a higher dose of orthovanadate over rutin (about 10-times) did not cause DCF formation means, that the product(s) of the reaction between rutin and orthovanadate (presumably $\mathrm{H}_{2} \mathrm{O}_{2}$ ) can react with $\mathrm{VO}_{4}{ }^{3-}$, as well. Hydrogen peroxide can react with orthovanadate forming peroxovanadate that can activate the cells thereafter [34]. Among the targets of these oxidative agents, there is nuclear factor- $\mathrm{kB}$ (NF-kB) [35]. However, pervanadate inhibits the I-KB degradation and NF- $\mathrm{KB}$ translocation to the nucleus in TNF- $\alpha$ treated cells $[36,37]$, pervanadate alone can activate NF- $\mathrm{\kappa B}$ by an alternative pathway, without proteolytic degradation of I- $\mathrm{\kappa B}$ [38]. After activation, NF- $\mathrm{KB}$ can induce the transcription of several genes, for example that of inducible nitric oxide synthase (iNOS) in macrophages $[39,40]$.

The role of NF- $\mathrm{KB}$ in mediating the action of rutin+orthovanadate is supported by the fact, that PDTC could inhibit the NO production of the cells activated by rutin+orthovanadate. However, the reason of the toxicity of PDTC at its highest concentration is not yet cleared. This toxicity was seen only with orthovanadate, and did not occure in case of PDTC plus $100 \mathrm{ng} / \mathrm{ml}$ LPS (data not shown).

The inhibitors of protein tyrosine kinases blocked the NO synthesis caused by rutin+orthovanadate, in a dose dependent manner. As genistein also has a hydrogen peroxide scavenging activity [23, 42, 43], its effective inhibitory dose was lower than that of tyrphostin-AG126 [24]. Since protein tyrosine kinase inhibitors can directly inhibit the activation of NF- $\mathrm{KB}$ [37], the activation of NF- $\mathrm{KB}$ by hydrogen peroxide and orthovanadate and/or peroxovanadate can be prevented by genistein and tyrphostinAG126. 
The synergistic action of rutin+orthovanadate on the LPS induced NO production means, that there is another pathway leading to activation of J774A.1 cells. This might be the common target NF-KB that can be activated by oxidative stress [35, 39] and by LPS $[41,44]$.

According to these results, it seems that the protein tyrosine phosphatase inhibitory effect of orthovanadate is different from the $\mathrm{H}_{2} \mathrm{O}_{2}$ production (that raises outside the cells), and it is additive to its synergistic action with rutin [1].

Both quercetin and rutin are prooxidants, but only quercetin showed capability to autooxidation, and production of hydrogen peroxide [45]. But, these results suggest, that under some circumstances, rutin can decompose, similarly to quercetin. The first step in the action of rutin plus orthovanadate toward the induction of iNOS by J774A.1 macrophages might be the vanadate catalysed autooxidation of rutin, followed by the activation of NF- $\mathrm{\kappa B}$.

The action of rutin+orthovanadate on the activity of phospholipase A2, topoisomerase IV and phosphatidylinositol 3-kinase, and that of the production of cytokines (interleukin-1 and tumor necrosis factor-alpha) remained to be investigated.

\section{REFERENCES}

1. Gordon, J.: Use of vanadate as protein-phosphotyrosine phosphatase inhibitor. Methods Enzymol. 201, 477-482 (1991).

2. Mayer, A. M., Brenic, S., Stocker, R., Glaser, K. B.: Modulation of superoxide generation in in vivo lipopolysaccharide-primed rat alveolar macrophages by arachidonic acid and inhibitors of protein kinase $\mathrm{C}$, phospholipase A2, protein serine-threonine phosphatase(s), protein tyrosine kinase(s) and phosphatase(s). J. Pharmacol. Exp. Ther. 274, 427-436 (1995).

3. Pandey, S. K., Anand-Srivastava, M. B., Srivastava, A. K.: Vanadyl sulfate-stimulated glycogen synthesis is associated with activation of phosphatidylinositol 3-kinase and is independent of insulin receptor tyrosine phosphorilation. Biochemistry 12, 987-996 (1998).

4. Yin, X., Davison, A. J., Tsang, S. S.: Vanadate-induced gene expression in mouse C127 cells: roles of oxygen derived active species. Mol. Cell Biochem. 115, 85-96 (1992).

5. Welsh, N.: A role for tyrosine kinase activation in interleukin-1 beta induced nitric oxide production in the insulin producing cell line RINm-5F. Biosci. Rep. 14, 43-50 (1994).

6. Nakaike, R., Shimokawa, H., Owada, M. K., Tokunaga, O., Yasutake, H., Kishimoto, T., Imada, C., Shiraishi, T., Egashira, K., Takeshita, A.: Vanadate causes synthesis of endothelium-derived NO via pertussis toxin-sensitive G protein in pigs. Am. J. Physiol. 271, H296-302 (1996).

7. Hibbs, J. B. Jr., Taintor, R. R., Vavrin, Z., Rachlin, E. M.: Nitric oxide: a cytotoxic activated macrophage effector molecule. Biochem. Biophys. Res. Commun. 157, 87-94 (1988).

8. van Acker, S. A., Tromp, M. N., Haenen, G. R., van der Vijgh, W. J., Bast, A.: Flavonoids as scavengers of nitric oxide radical. Biochem. Biophys. Res. Commun. 214, 755-759 (1995).

9. Skaper, S. D., Fabris, M., Ferrari, V., Dalle-Carbonare, M., Leon, A.: Quercetin protects cutaneous tissue-associated cell types including sensory neurons from oxidative stress induced by glutathione depletion: cooperative effects of ascorbic acid. Free Radic. Biol. Med. 22, 669-678 (1997). 
10. Kostyuk, V. A., Potapovich, A. I., Speransky, S. D., Maslova, G. T.: Protective effect of natural flavonoids on rat peritoneal macrophages injury caused by asbestos fibers. Free Radic. Biol. Med. 21, 487-493 (1996)

11. Schmitt, A. S., Salvayre, R., Delchambre, J., Négre-Salvayre, A.: Prevention by alpha-tocopherol and rutin of glutathione and ATP depletion induced by oxidized LDL in cultured endothelial cells. Br. J. Pharmacol. 116, 1985-1990 (1995).

12. Negre-Salvayre, A., Reaud, V., Hariton, C., Salvayre, R.: Protective effect of alpha-tocopherol, ascorbic acid and rutin against peroxidative stress induced by oxidized lipoproteins on lymphoid cell lines. Biochem. Pharmacol. 42, 450-453 (1991).

13. Kunizane, H., Ueda, H., Yamazaki, M.: Screening of phagocyte activators in plants; enhancement of TNF production by flavonoids. Yakugaku Zasshi 115, 749-755 (1995)

14. Lindahl, M., Tagesson, C.: Flavonoids as phospholipase A2 inhibitors: importance of their structure for selective inhibition of group II phospholipase A2. Inflammation 21, 347-356 (1997).

15. Bernard, F. X., Sable, S., Cameron, B., Provost, J., Desnottes, J. F., Crouzet, J., Blanche, F. Glycosylazed flavones as selective inhibitors of topoisomerase IV. Antimicrob. Agents Chemother. 41, 992-998 (1997)

16. McCall, T. B., Feelish, M., Palmer, R. M. J., Moncada, S.: Identification of N-iminoethyl-L-ornithine as an irreversible inhibitor of nitric oxide synthase in phagocytic cells. Br. J. Pharmacol. 102, 234-238 (1991).

17. Green, L. C., Wagner, D. A., Glogowski, J., Skipper, P. L., Wishnok, J. S., Tannenbaum, S. R. Analysis of nitrate, nitrite, and $[15 \mathrm{~N}]$ nitrate in biological fluids. Anal. Biochem. 126, 131-138 (1982).

18. Gross, S. S., Stuehr, D. J., Aisaka, K., Jaffe, E. A., Levi, R., Griffith, O. W.: Macrophage and endothelial cell nitric oxide synthesis: cell-type selective inhibition by NG-aminoarginine, NGnitroarginine and NG-methylarginine. Biochem. Biophys. Res. Commun. 170, 96-103 (1990).

19. Roy, S., Noda, Y., Eckert, V., Traber, M. G., Mori, A., Liburdy, R., Packer, L.: The phorbol 12myristate 13-acetate (PMA)-induced oxidative burst in rat peritoneal neutrophils is increased by a $0.1 \mathrm{mT}(60 \mathrm{~Hz})$ magnetic field. FEBS Letters 376, 164-166 (1995).

20. Gillissen, A., Scharling, B., Jaworska, M., Bartling, A., Rasche, K., Schultze-Werninghaus, G.: Oxidant scavenger function of ambroxol in vitro: a comparison with $\mathrm{N}$-acetylcysteine. Res. Exp. Med. 196, 389-398 (1997).

21. Gillissen, A., Jaworska, M., Orth, M., Coffiner, M., Maes, P., App, E. M., Cantin, A. M., SchultzeWerninghaus, G.: Nacystelyn, a novel lysine salt of N-acetylcysteine, to augment cellular antioxidant defence in vitro. Respir. Med. 91, 159-168 (1997).

22. Yan, C. Y. I., Ferrari, G., Green, L. A.: N-acetylcysteine-promoted survival of PC12 cells is glutathione-independent but transcription-dependent. J. Biol. Chem. 270, 26827-26832 (1995).

23. Akiyama, M., Ishida, J., Nakagawa, S., Ogawara, H., Watanabe, S.: Genistein, a specific inhibitor of tyrosine-specific protein kinases. J. Biol. Chem. 262, 5592-5595 (1987).

24. Novogrodsky, A., Vanichkin, A., Patya, M., Gazit, A., Osherov, N., Levitzki, A.: Prevention of lipopolysaccharide-induced lethal toxicity by tyrosine kinase inhibitors. Science 264, 1319-1322 (1994).

25. Afanas'ev, I. B., Dorozhko, A. I., Brodskii, A. V., Kostyuk, V. A., Potapovitch, A. I.: Chelating and free radical scavenging mechanisms of inhibitory action of rutin and quercetin in lipid peroxidation. Biochem. Pharmacol. 38, 1763-1769 (1989).

26. Obrig, T. G., Culp, W. J., McKeehan, W. L., Hardesty, B.: The mechanism by which cycloheximide and related glutarimide antibiotics inhibit peptide synthesis on reticulocyte ribosomes. J. Biol. Chem. 246, 174-181 (1971).

27. Cypriani, B., Limasset, B., Carrie, M. L., Le Doucen, C., Roussie, M., De Paulet, A. C., Damon, M.: Antioxidant activity of micronized diosmin on oxygen species from stimulated human neutrophils. Biochem. Pharmacol. 45, 1531-1535 (1993). 
28. Robak, J., Gryglewski, R. J.: Flavonoids are scavengers of superoxide anions. Biochem. Pharmacol. 37, 837-841 (1988)

29. Jovanovic, S. V., Steenken, S., Tosic, M., Marjanovic, B., Simic, M.: Flavonoids as antioxidants. J. Am. Chem. Soc. 116, 4846-4851 (1994).

30. Lebel, C. P., Ischiropoulos, H., Bondy, S. C.: Evaluation of the probe 2',7'-dichlorofluorescin as an indicator of reactive oxygen species formation and oxidative stress. Chem. Res. Toxicol. 5, 227-231 (1992).

31. Zhu, H., Bannenberg, G. L., Moldeus, P., Shertzer, H. G.: Oxidation pathways for the intracellular probe 2',7'-dichlorofluorescein. Arch. Toxicol. 68, 582-587 (1994).

32. Flohé, L., Ötting, F.: Superoxide dismutase assays. Methods Enzymol. 105, 93-104 (1984)

33. Aebi, H.: Catalase in vitro. Methods Enzymol. 105, 121-126 (1984).

34. Kazazi, F., Koehler, J. K., Klebanoff, S. J.: Activation of the HIV long terminal repeat and viral production by $\mathrm{H}_{2} \mathrm{O}_{2}$-vanadate. Free Radic. Biol. Med. 20, 813-820 (1996).

35. Meyer, M., Schreck, R., Baeuerle, P. A.: $\mathrm{H}_{2} \mathrm{O}_{2}$ and antioxidants have opposite effects on activation of NF-kappa B and AP-1 in intact cells: AP-1 as secondary antioxidant-responsive factor. EMBO J. 12, 2005-2015 (1993).

36. Menon, S. D., Guy, G. R., Tan, Y. H.: Involvement of a putative protein-tyrosine phosphatase and I kappa B-alpha serine phosphorylation in nuclear factor kappa B activation by tumor necrosis factor. J. Biol. Chem. 270, 18881-18887 (1995).

37. Singh, S., Aggarwal, B. B.: Protein-tyrosine phosphatase inhibitors block tumor necrosis factordependent activation of the nuclear transcription factor NF-kappa B. J. Biol. Chem. 270, 10631-10639 (1995).

38. Imbert, V., Rupec, R. A., Livolsi, A., Pahl, H. L., Traenckner, E. B., Mueller-Dieckmann, C., Farahifar, D., Rossi, B., Auberger, P., Baeuerle, P. A., Peyron, J. F.: Tyrosine phosphorylation of I kappa B-alpha activates NF-kappa B without proteolytic degradation of I kappa B-alpha. Cell 86, 787-798 (1996).

39. Schreck, R., Meyer, B., Männel, D. N., Dröge, W., Baeuerle, P. A.: Dithiocarbamates as potent inhibitors of nuclear factor kappa B activation in intact cells. J. Exp. Med. 175, 1181-1194 (1992).

40. Sherman, M. P., Aeberhard, E. E., Wong, V. Z., Griscavage, J. M., Ignarro, L. J.: Pyrrolidine dithiocarbamate inhibits induction of nitric oxide synthase activity in rat alveolar macrophages. Biochem. Biophys. Res. Commun. 191, 1301-1308 (1993).

41. Kurata, S., Matsumoto, M., Tsuji, Y., Nakajima, H.: Lipopolysaccharide activates transcription of the heme oxygenase gene in mouse M1 cells through oxidative activation of nuclear factor kappa B. Eur. J. Biochem. 239, 566-571 (1996).

42. Wei, H., Bowen, R., Cai, Q., Barnes, S., Wang, Y.: Antioxidant and antipromotional effects of the soybean isoflavone genistein. Proc. Soc. Exp. Biol. Med. 208, 124-130 (1995).

43. Wei, H., Wei, L., Frenkel, K., Bowen, R., Barnes, S.: Inhibition of tumor promoter-induced hydrogen peroxide formation in vitro and in vivo by genistein. Nutr. Cancer 20, 1-12 (1993).

44. Ishikawa, Y., Mukaida, N., Kuno, K., Rice, N., Okamoto, S., Matsushima, K.: Establishment of lipopolysaccharide-dependent nuclear factor kappa B activation in a cell-free system. J. Biol. Chem. 270, 4158-4164 (1995)

45. Canada, A. T., Gianella, E., Nguyen, T. D., Mason, R. P.: The production of reactive oxygen species by dietary flavonols. Free. Radic. Biol. Med. 9, 441-449 (1990). 